\title{
Mechanical Conditioning of Greenhouse-grown Transplants
}

\author{
Joyce G. Latimer and \\ Reuben B. Beverly
}

Additional index words. seedling, height control, stress, brushing, shaking, PGR, stress tolerance, transplant handling

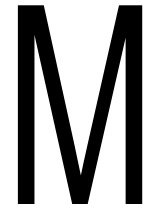

echanical conditioning is physical stimulation or stress deliberately applied in order to manage plant growth and quality (Latimer, 1991). Mechanical stress applied naturally or under controlled conditions alters growth, thus reducing the mass and size of major plant parts. The methods of applying mechanical conditioning in research include rubbing stems, brushing shoots, shaking potted plants and whole flats, vibrating pots or plants, and perturbing plants with water, forced air, or wind. The procedures most studied for transplants have been wind, brushing, and shaking; all of which result in physical displacement of the growing points.

\section{Why mechanical conditioning?}

In growing transplants, it is necessary to produce plants that will: 1) withstand the physical rigors of handling and transplanting ,2) survive the stress of moving from protected to field environments, 3) become established and resume active growth soon after transplanting, and 4) produce acceptable yields without reduction or delay compared to alternative stand establishment methods. Ideally, the method of growth control should improve post-transplant performance, and the acceptable transplants should be short and stocky with thick, strong stems and deep green color. Although various cultural practices (as indicated by other papers in this colloquium) can contribute to the production of acceptable transplants, until recently chemical plant growth regulators (PGRs) provided one of the most convenient and consistent management methods. With the loss of daminozide (Alar) from the market in 1989, grow- 
ers were left with no growth retardants labeled for use on vegetable transplants. Consumers' concern about chemical contamination of food crops, coupled with growers' desires to be environmentally responsible, may discourage the development of replacement chemical growth regulators. Therefore, growers need nonchemical methods to control plant growth. As we show here, mechanical conditioning can substitute for chemical growth regulators to produce desirable characteristics in vegetable transplants, such as size and conformation, color, viability and vigor following transplanting, and ultimate productivity.

\section{Benefits of mechanical conditioning}

Effectiveness equivalent to PGR treatment. Mechanical conditioning can reduce plant height by $20 \%$ to more than $50 \%$ when compared to untreated plants. These reductions in growth are similar to those attained with chemical plant growth regulators. For example, potted tomato (Lycopersicon esculentum Mill.) plants shaken continuously at » $130 \mathrm{rpm}$ for 15 days were $\approx 20 \%$ shorter than undisturbed controls, while plants treated with $5000 \mathrm{ppm}$ daminozide were » $30 \%$ shorter (Latimer and Mitchell, unpublished data). Adler and Wilcox (1987) reported a 48\% reduction in height of tomato plants treated with either chlormequat chloride or thigmic stress (stem rubbing). Newport and Carlson (1991) combined drought and negative temperature differential (-DIF) with shaking to attain a $41 \%$ height reduction of tomato seedlings grown in flats. Vibration (via aeration from beneath the bench) of high-density tomato seedlings reduced plant height by $41 \%$ (Liptay, 1985). Brushing has reduced tomato plant height by as much as $55 \%$ in a responsive cultivar such as 'Sunny' (Latimer, unpublished data). Although tomato is probably the crop most studied with respect to mechanical conditioning, brushing is quite effective on a large number of other vegetable crops, including eggplant (Solanum melongena L.), cucumber (Cucumis sativus L.), squash (Cucurbita pepo L.), watermelon (Citrullus lanatus L.), and some cultivars of broccoli (Brassica oleracea L.) and cabbage (Brassica oleracea L.) (Latimer and Baden, 1991). The method of brushing transplants in those studies used a pole that ran over a bench on a track attached to the bench (Baden and Latimer, 1992) to brush the top onethird of the plants 40 times $(\approx 1.5 \mathrm{~min}$ ) twice daily for all crops, except tomato, which were brushed 80 times twice daily. This system requires that the tops of all brushed plants be uniform to receive similar treatment, so shorter plants (e.g., lessvigorous cultivars) must be elevated to the same height as taller plants.

Manageable growth reduction. The degree of growth reduction depends on the duration or intensity of the mechanical conditioning treatment. Adler and Wilcox (1987) found that the longer a wind or a rubbing treatment was applied, the more plant height of tomato was reduced. In addition, the timing of treatment initiation, which affects treatment duration, affected the degree of growth reduction. For example, as the initiation of brushing tomato was delayed from the cotyledonary stage to the third-true-leaf-stage (resulting in a range of 8 to 18 days treatment), stem length reductions decreased from $43 \%$ to $29 \%$ for 'Sunny' and from $37 \%$ to $17 \%$ for 'Wolfpack', compared to untreated plants (Latimer, unpublished data). Eggplant stem length showed similar responses, with little additional effect on leaf area or shoot dry weight (data not presented). Thus, mechanical conditioning provides flexibility in growth control; i.e., the treatment can be managed to reduce plant growth as much or as little as desired.

Improves plant color and uniformity. In addition to growth control, mechanical conditioning improves plantappearance. Specific chlorophyll content is higher in mechanically conditioned tomato (Mitchell et al., 1975) eggplant (Latimer and Mitchell, 1988) lettuce (Lactuca sativa L.), and celery (Apium graveolens L.) (Biddington and Dearman, 1985a). In addition, mechanical conditioning increases specific leaf weight of tomato (Heuchert and Mitchell, 1983) eggplant (Latimer et al., 1986) lettuce, celery, and cauliflower (Brassica oleracea L.)(Biddington and Dearman, 1985a). The darker-green, thicker leaves, combined with shorter stems enhance the healthy, vigorous appearance of brushed transplants. We also have observed that brushing (or mechanical conditioning) greatly improved plant uniformity in the flat.

Greater stem and petiole strength. Although shaking reduced tomato stem diameter, both ultimate shear strength and the modulus of rupture of stems and petioles were increased in shaken plants (Heuchert et al., 1983). Further analysis of stem structural components indicated an increase in percent cellulose in the fiber component of the shaken tomato stems. Rubbed bean (Phaseolus vulgaris L.) stems were stronger than unrubbed stems (Jaffe et al., 1984) and stem strength increased with increasing duration of treatment up to 14 days. The value of increased stem strength in stand establishment is apparent. We have observed clear differences in the "toughness" of treated plants and recorded less breakage during transplanting. In addition, plants maintained a more upright habit when planted or transferred to outdoor conditions (Latimer and Mitchell, 1988). Stem strength also should prove important during shipping and subsequent handling.

Potential increase in stress tolerance. The value of mechanical conditioning in improving tolerance to stress has been less consistent. Although brushing increased drought tolerance of soybean [Glycine max (L.) Merr.] (Suge, 1980) brushing slightly decreased the drought tolerance of celery, cauliflower, and lettuce (Biddington and Dearman, 1985b). In related work (Latimer, unpublished data), brushed and untreated tomato plants were planted subsequently in pots of sand, and either watered to prevent drought stress or subjected to cyclic drought stress for 12 days. In that study, brushing did not induce measurable resistance to drought stress. Drought reduced the rate of dry weight gain after transplanting for both brushed and untreated plants. Although brushed plants had lower initial dry weights, the rate of increase in dry weight after transplanting was similar to that of untreated plants under either watered or drought-stressed treatments.

Mechanical conditioning does improve at least one aspect of stress tolerance. In tomato plants subjected to severe drought stress, prior conditioning by brushing reduced the occurrence of "pithy" or "hollow" stems from 95\% among unbrushed plants to only $5 \%$ (Pressman et al., 1983). Perhaps this increase in stress tolerance is due to the structural changes noted by Heuchert et al. (1983) and Jaffe et al. (1984).

Enhancement of stand establishment in the field. Regardless of direct effects on stress tolerance, mechanical conditioning can improve field establishment of transplants. Liptay (1985) noted that, while vibrated tomato plants had 34\% less shoot dry weight at the time of transplanting, there was no difference in shoot dry weight after 3 weeks in the field. In two of three broccoli tests, brushed transplants increased in shoot dry weight more rapidly than untreated plants during the first 14 to 21 days after field transplanting (Latimer, 1990). This may be due to the net effect of an accumulation of other growth responses, including increased specific leaf weight and specific chlorophyll content, more upright habit with stronger stems and petioles, and less leaf area, which could reduce water loss.

Minor effects on crop yield. Although cultivars vary in their response to mechanical conditioning, generally, little or no effect on yield occurs with plants treated only during the transplant production stage. Brushing greenhousegrown seedlings did not affect subsequent head weight of lettuce (Wurr et al., 1986) or broccoli (Latimer, 1990) or fruit yield of four cultivars of tomato (Johjima et al., 1992) or of three of four cultivars of cucumber (Latimer et al., 1991). However, pretransplant brushing did delay or reduce fruit production in 'Sunrise' tomato in one experiment (Beverly et al., 1992). Finally, mechanical conditioning during crop production has reduced yield of tomato (Buitelaar, 1989; Johjima et al., 1992) and potato (Solanum tuberosum L.) (Akers and Mitchell, 1985).

\section{Disadvantages of mechanical conditioning}

At present, large-scale commercial adoption of brushing in transplant production isconstrained by both logistical and physiological considerations. Brushing by hand is too labor-intensive to be economical for commercial application. Fur- 
thermore, mechanical conditioning has the potential to physically damage transplants. For example, bell pepper (Capsicum annuum L.) transplants are very sensitive to leaf and shoot tip damageduring brushing. The severity of this damage varies with cultivar and light intensity. Under shaded conditions, brushed plantsexhibited more damage than under full sunlight (Latimer, unpublished data). Mechanical conditioning also may increase the spread of pathogens among treated plants and reduce final crop yield. While some of the current constraints to adoption of mechanical conditioning are researchable problems, some are simply matters of engineering or economics.

\section{Future potential for mechanical conditioning}

Mechanical conditioning must be automated to make it commercially feasible. Growers prefer applying treatments during non-working hours and desire exact recipes for growth control of individual crops. With the differences in cultivar and species responses, this request will be difficult to fulfill, as researchers must define cultivar differences in response to mechanical conditioning further. There is a need to identify the factors affecting plant damage in response to mechanical conditioning treatments and develop methods that reduce damage to sensitive cultivars or species.

Development of alternative methods that reduce physical contact with young plant tissue, such as air blasts (Beyl and Mitchell, 1977) or shaking of entire benches, may be more acceptable for a wider variety of crops. These methods also would obviate the need to maintain crops at a uniform height, as is required for brushing. The impact of conditioning methods on insect and disease management in the greenhouse and following transplanting also must be addressed. Our hypothesisthat mechanical conditioning improves transplant shipping tolerance needs to be tested.

Although mechanical conditioning may not attain the ultimate goal of conditioning (to control transplant growth during production and enhance post-transplant productivity), it generally does provide acceptable growth control with no detrimental effects on crop productivity.

\section{Literature Cited}

Adler, P.R. and G.E. Wilcox. 1987. Salt stress, mechanical stress, or chlormequat chloride effects on morphology and growth recovery of hydroponic tomato transplants. J. Amer. Soc. Hort. Sci. 112:22-25.
Akers, S.W and C.A. Mitchell. 1985. Seismic stress effects on reproductive structures of tomato, potato, and marigold. HortScience 20:684-486.

Baden, S.A. and J.G. Latimer, 1992. An effective system for brushing vegetable transplants for height control. HortTechnology 2:412-414.

Beverly, R.B., J.G. Latimer, and R.D. Oetting. 1992. Effect of root cell size and brushing on transplant growth and field establishment of Sunrise tomato under a line-source irrigation variable. Proc. Stand Estab. Hort. Crops Conf., Nov. 1992. 101:249258.

Beyl, CA. and C.A. Mitchell. 1977 Automated mechanical stress application for height control of greenhouse chrysanthemum. HortScience 12:575577.

Biddington, N.L. and A.S. Dearman. 1985a. The effect of mechanically induced stress on the growth of cauliflower, lettuce and celery seedlings. Ann. Bot. 55:109-119.

Biddington, N.L. and A.S. Dearman. 1985b. The effect of mechanically-induced stress on water loss and drought resistance in lettuce, cauliflower and celery seedlings. Ann. Bot. 56:795-802.

Buitelaar, K. 1989. Tomatoes. Plant movementcan lead to a lower yield (in Dutch). Groenten en Fruit 44(29):31. [Hort. Abstr. 59:7515.]

Heuchert, J.C. and C.A. Mitchell. 1983. Inhibition of shoot growth in greenhouse-grown tomato by periodic gyratory shaking. J. Amer. Soc. Hort. Sci. 108:795-800.

Heuchert, J.C., J.S. Marks, and C.A. Mitchell. 1983. Strengthening of tomato shoots by gyratory shaking. J. Amer. Soc. Hort. Sci. 108:801-805.

Jaffe, M.J., F.W. Telewski, and P.W. Cooke. 1984. Thigmomorphogenesis: On the mechanical properties of mechanically perturbed bean plants. Physiol. Plant. 62:73-78.

Johjima, T., J.G. Latimer, and H. Wakita. 1992. Brushing influences transplant growth and subsequent yield of four cultivars of tomato and their hybrid lines. J. Amer. Soc. Hort. Sci. 117:384388.

Latimer, J.G. and S.A. Baden. 1991. Brushing vegetable transplants for height control: Survey of cultivar responses. Proc. 18th Annu. Mtg. Plant Growth Regulat. Soc. Amer., Boston. p. 166-167.

Latimer, J.G. and CA. Mitchell. 1988. Effects of mechanical stress or abscisic acid on growth, water status, and leaf abscisic acid content on eggplant seedlings. Scientia Hort. 36:37-46.

Latimer, J.G. 1990. Drought or mechanical stress conditioning affect broccoli seedling growth and transplantestablishment, but not yield. HortScience 25:1233-1235

Latimer, J.G. 1991. Mechanical conditioning for control of growth and quality of vegetable transplants. HortScience 26:1456-1461.

Latimer, J.G., T. Johjima, and K. Harada. 1991. The effect of mechanical stress on transplant growth and subsequent yield of four cultivars of cucumber. Scientia Hort. 47:221-230.

Latimer, J.G., T. Pappas, and C.A. Mitchell. 1986. Growth responses of eggplant and soybean seedlings to mechanical stress in greenhouse and outdoor environments. J. Amer. Soc. Hort. Sci. 111:694-698.

Liptay, A. 1985. Reduction of spindliness of tomato transplants grown at high densities. Can. J. Plant Sci. 65:797-801.

Mitchell, C.A., C.J. Severson, J.A. Watt, and P.A. Hammer. 1975. Seismomorphogenic regulation of plant growth. J. Amer. Soc. Hort. Sci. 100:161-165.

Newport, S.O. and W.H. Carlson. 1991. Height control of tomato transplants. HortScience 26:767. (Abstr.)

Pressman, E., M. Huberman, B. Aloni, and M.J. Jaffe. 1983. Thigmomorphogenesis: The effect of mechanical perturbation and ethrel on stem pithiness in tomato [Lycopersicon esculentum (Mill.)] plants. Ann. Bot. 52:93-100.

Suge, H. 1980. Dehydration and drought resistance in Phaseolus vulgaris as affected by mechanical stress. Rpt. Inst. Agr. Res. Tohoku Univ. 31:1-10.

Wurr, D.C.E., J.R. Fellows, and P. Hadley. 1986. The influence of supplementary lighting and mechanically-induced stress during plant raising on transplant and maturity characteristics of crisp lettuce. J. Hort. Sci. 61:325-330. 